\title{
EFFECT OF DIFFERENT FEEDING LEVELS ON THE PRODUCTIVE PERFORMANCE OF LACTATING EGYPTIAN BUFFALOES
}

\author{
N.E. El-Bordeny ${ }^{1}$, R.M.A. Gawad ${ }^{2}$, H.M. Ebied ${ }^{2}$ and A.E.M. Mahmoud ${ }^{3}$ \\ ${ }^{1}$ Animal Production Department, Faculty of Agriculture, Ain Shams University, Cairo, 11241, Egypt. \\ ${ }^{2}$ Dairy Sciences Department, National Research Centre, 33 Buhouth St., Dokki, Giza, 12311, Egypt. \\ ${ }^{3}$ Animal Production Department, Faculty of Agriculture, Cairo University, Giza, 12613, Egypt.
}

(Received 6/11/2017, accepted 26/12/2017)

\section{SUMMARY}

$\mathrm{N}$ utrient requirements of dairy animals are the main factor affecting on productive and reproductive performance. So, the objective of the study was to evaluate the nutrient requirements of dairy cattle performed by NRC could be to meet lactating Egyptian buffalo's nutrient requirements. Twenty four lactating buffaloes at third to fifth seasons of lactation and weighed on average $514 \pm 12.15 \mathrm{~kg}$ were used in the current study. The animals were divided randomly into three groups (eight animals each) to get three feeding levels of NRC requirements. Three feeding levels were performed to meet $80 \%\left(\mathrm{~T}_{1}\right), 100 \%$ $\left(\mathrm{T}_{2}\right)$ and $120 \%\left(\mathrm{~T}_{3}\right)$ of NRC allowances for dairy cattle. The obtained results indicated that dry matter intake (DMI) $(\mathrm{kg} / \mathrm{d})$ has a gradual and significant increase $(\mathrm{P}<0.05)$ by increasing feeding level. Apparent dry matter (DM), organic matter (OM), crude protein (CP) and crude fiber (CF) digestibility were not significantly affected by treatments. Milk yield, $4 \%$ fat corrected milk (4\% FCM) and energy corrected milk $(\mathrm{ECM})(\mathrm{kg} / \mathrm{d})$ were having a gradual increase by increasing feeding level. Milk composition (\%) was not significantly affected by treatments; however, milk composition yields (g/d) were significantly increased $(\mathrm{P}<0.05)$ by increasing feeding levels. Feed conversion for milk yield, 4\% FCM and ECM $(\mathrm{Kg} / \mathrm{Kg} \mathrm{DMI})$ were significantly $(\mathrm{P}<0.05)$ enhanced by increasing feeding level according to NRC requirements. It can be concluded that the NRC requirements for dairy cattle are not enough for Egyptian buffaloes under the conditions of this study. Also, increasing feeding level for buffaloes above NRC allowances for dairy cattle could enhance the productive performance for Egyptian buffaloes.

Keywords: buffaloes, NRC requirements, feeding, milk and digestibility.

\section{INTRODUCTION}

Milk yield for dairy animal continue to increase as a result of nutrition improvement, genetic selection and disease control as well as management improvement procedures. In lactating dairy animal, insufficient supply of nutrient requirements led to a decline in milk yield and loss of body weight. In addition, severe and prolonged energy and protein deficiency depresses reproductive function (NRC, 2001).

In this context, milk production of buffalo has increased substantially in recent years because of its superior quality of milk and better ability of buffalo to adapt to different climates especially hot and humid climate and to poor quality crop residue (Calabro et al., 2003; Paul and Lal, 2010 and Paul, 2011). Hence, knowledge of animal requirements becomes very important, in order to optimize animal rationing in the different productive phases and achieve major advances in animal welfare and farm economy (Paul, 2011).

Traditional system of raising animals either by grazing or by providing green fodder with or without any supplementation are not satisfactory as they are unable to meet the nutrient requirement of animals particularly energy, protein and minerals, especially, energy and protein requirements considered of the most critical nutrients which have the biggest effect on productive performance. Earlier studies (Grummer and Carroll, 1988 and Gong et al., 2002) reported that sufficient dietary energy is an important factor in 
lactating animals which may prevent negative energy balance and other metabolic disorders. Lactating animals fed low energy diet may able to produce equal quantity of milk than diets or above NRC recommendations, but decline rapidly after twelve weeks of lactation (Hoogendoorn and Grieve, 1970).

In Egypt, Nili-Ravi buffalo, including Egyptian buffaloes, has more milk potential which can better exploited by appropriate feeding, the buffalo's farms have not equal feeding systems due to differences between local types of animal, availability of feedstuffs, which will affect on feed efficiency, meat and milk production. The population of buffaloes in Egypt has nearly 3.96 million head, representing $47 \%$ of dairy animals in Egypt (8.704 million head, cattle and buffaloes) (FAO, 2014), which contribute about 47 $\%(2,614,500$ ton $)$ of total milk production $(5,900,500$ ton) in Egypt.

Literature is deficient with reference to the nutritional needs of buffalo in general and lactating buffaloes in particular. The earlier reports to appropriate of the requirements for feeding Egyptian buffaloes were carried out in 1950s and 1980s by Ghoneim (1967), Shehata (1971) and El-Serafy and ElAshry(1988). However, the various standard nutritional requirements for buffaloes have been conducted in India which reported by Kearl (1982) and updated by Paul et al. (2002 and 2003).

Keeping in view these facts, in the present study, the NRC allowances for big breed of dairy cattle were used as a standard to evaluate if NRC requirements for dairy cattle can be used to cover Egyptian buffaloes energy and protein requirements.

\section{MATERIALS AND METHODS}

This study was carried out at Agricultural Experimental Station, Faculty of Agriculture, Ain Shams University, Kalubyia, Egypt and the Animal Production Laboratory of Diary Science Department, National Research Center, Dokki, Giza, Egypt in cooperation with Animal Production Department, Faculty of Agriculture, Cairo University, Giza, Egypt.

\section{Animals, diets, feeding and experimental design:}

To investigate the impact of feeding nutritionally balanced rations with different three levels of NRC requirements on milk production and buffalo's performance, twenty-four lactating buffaloes at third to fifth seasons of lactation and weighed on average $514 \pm 12.15 \mathrm{~kg}$ were divided into three groups (eight animals each) using complete random design. The animals started on their assigned experimental feed approximately 1 day after parturition. The lactation trial lasted about 180 days. The animals were kept and fed individually in an insulated barn. The animals were fed according to use the tables of NRC requirements (NRC, 2001) to meet the animals requirements (maintenance and production). Group one $\left(\mathrm{T}_{1}\right)$ of buffaloes was fed on $80 \%$ of NRC requirements which introduced to the buffaloes at the same weight and production volume, while group two and three $\left(\mathrm{T}_{2}\right.$ andT $\left._{3}\right)$ were fed on 100 and $120 \%$ of NRC requirements. The ration was offered twice daily at 07:00 and 18:00 and the animals had free access to fresh water. The daily offered feed and orts were individually recorded for each animal. The ingredient and chemical composition of total mixed ration formulation of experimental lactating buffaloes are presented in Table (1).

\section{Apparent digestibility:}

Two digestibility trials were applied at 45 and 90 days after parturition using all animals from each group. Silica was used as an internal marker for determining the digestibility according to the method reported by Van Kulen and Young (1977). At $4 \mathrm{~h}$ after the morning feeding, fecal samples (approximately $100 \mathrm{~g}$ ) were collected from the rectum for three successive days and pooled by buffalo for each period. The fecal samples were dried at $55{ }^{\circ} \mathrm{C}$ for $48 \mathrm{~h}$, and then ground to pass a $1 \mathrm{~mm}$ sieve in a feed mill for chemical analysis. The digestibility coefficients of certain nutrients were calculated according to the following formula:

$$
\text { Digestibility }=100-\left[100 x \frac{\% \text { indicator in feed }}{\% \text { indicator in feces }} \times \frac{\% \text { nutrient in feces }}{\% \text { nutrient in feed }}\right]
$$


Table (1): Ingredient and chemical composition of total mixed ration of experimental lactating buffaloes

\begin{tabular}{|c|c|}
\hline Ingredient $(\mathrm{g} / \mathrm{kg})$ & $\mathrm{g} \mathrm{kg}^{-1}$ \\
\hline Berseem & 700 \\
\hline Rice straw & 59.20 \\
\hline Yellow corn & 130 \\
\hline Soybean meal & 54.76 \\
\hline Wheat bran & 36.13 \\
\hline Sunflower meal & 14.45 \\
\hline Calcium carbonate & 3.41 \\
\hline Minerals and Vitamins $^{a}$ & 1.40 \\
\hline Salt & 0.70 \\
\hline Chemical composition (g/kg DM) & $\mathrm{g} \mathrm{kg}^{-1}$ \\
\hline Dry matter & 364.0 \\
\hline Organic matter & 885.3 \\
\hline Crude protein & 128.2 \\
\hline Ether extract & 30.32 \\
\hline Crude fiber & 164.9 \\
\hline $\mathrm{NE}_{\mathrm{L}}(\mathrm{Mcal} / \mathrm{kgDM})^{\mathrm{b}}$ & 1.75 \\
\hline \multicolumn{2}{|c|}{$\begin{array}{l}{ }^{a} \text { Contained } 141 \mathrm{~g} / \mathrm{kg} \text { of } \mathrm{Ca}, 27 \mathrm{~g} / \mathrm{kg} \text { of } \mathrm{P}, 65 \mathrm{~g} / \mathrm{kg} \text { of } \mathrm{Mg}, 14 \mathrm{~g} / \mathrm{kg} \text { of S, } 120 \mathrm{~g} / \mathrm{kg} \text { of } \mathrm{Na}, 6 \mathrm{~g} / \mathrm{kg} \text { of K, } 944 \mathrm{mg} / \mathrm{kg} \text { of Fe, } \\
1613 \mathrm{mg} / \mathrm{kg} \text { of } \mathrm{Zn}, 484 \mathrm{mg} / \mathrm{kg} \text { of Cu,1748mg of Mn, 58mg/kg of I, } 51 \mathrm{mg} / \mathrm{kg} \text { of Co, } 13 \mathrm{mg} / \mathrm{kg} \text { of Se, 248,000 U/kg of } \\
\text { vitamin A, 74,000 UI/kg of vitamin D } 3 \text { and } 1656 \mathrm{IU} / \mathrm{kg} \text { of vitamin E. } \\
{ }^{b} \text { Calculated using published values of feed ingredients (NRC, 2001). }\end{array}$} \\
\hline
\end{tabular}

\section{Sample collection and analyses:}

Samples of feed ingredients were subjected for chemical analyses. Milk samples were obtained once every two weeks from each buffalo for two consecutive milking and pooled within buffalo relative to production to obtain one composite milk sample per buffalo for determine milk composition. Milk samples were stored at $+4^{\circ} \mathrm{C}$ until chemical analysis. Blood samples were collected from all buffaloes on $15,30,45,60,75,90,120,150$ and 180 days postpartum at $4 \mathrm{~h}$ after the morning feeding to determine some blood parameters concentrations. Blood samples were withdrawn from the jugular vein into vacutainer tubes. The blood serum were obtained by centrifuging the blood samples $2 \mathrm{~h}$ after collection at $4000 \mathrm{rpm}$ for 15 minutes. Blood serum was transferred into a clean and dry glass vials and stored at $-20^{\circ} \mathrm{C}$ for subsequent specific chemical analysis. Total mixed ration (TMR) and feces samples DM, EE, CF, CP and ash were determined according to AOAC (1995). Organic matter was determined by difference between DM and ash content. The concentration of neutral detergent fiber (NDF) and acid detergent fiber (ADF) in TMR was determined with sodium sulfite and heat stable $\alpha$-amylase and expressed exclusive of residual ash (Van Soest et al., 1991). Blood serum samples were analyzed for total protein, albumin, total lipid, ALT, AST, creatinin and urea; using commercial kits (SPINREACT, A. A. - Ctra. Santa Coloma, Girona, Spain). Globulin was calculated by difference between total protein and albumin. Milk samples were analyzed for total solids, fat, total protein and lactose by infrared spectrophotometry (Foss 120 Milko-Scan, Foss Electric, Hillerød, Denmark). Solids-not-fat (SNF) was calculated by difference. Fat corrected milk (4\% fat) was calculated according to equation of Gaines (1928); while energy corrected milk (ECM) was calculated according to equation of Tyrrell and Reid (1965) as follow, respectively:

$$
\begin{gathered}
4 \% \mathrm{FCM}=0.4 \text { milk yield }(\mathrm{gm})+15 \text { fat yield }(\mathrm{gm}) \\
\mathrm{ECM}=0.327 \times \text { milk yield }(\mathrm{kg})+12.95 \mathrm{x} \text { fat yield }(\mathrm{kg})+7.20 \mathrm{x} \text { protein }(\mathrm{kg})
\end{gathered}
$$

Energy balance was calculated for each buffalo. Energy of maintenance was calculated using metabolic body weight (BW) as (BW ${ }^{0.75}$ kilograms) x 0.08 (mega calories per kilogram) (NRC, 2001). Energy of BW change was assumed to be $5.12 \mathrm{Mcal} / \mathrm{kg}$ of gain or $4.92 \mathrm{Mcal} / \mathrm{kg}$ of loss (NRC, 2001). Milk energy was calculated as the quantity of ECM produced (kilograms) x 0.692 (megacalories per kilogram) (Tyrrell and Reid, 1965). Intake of net energy for lactation $\left(\mathrm{NE}_{\mathrm{LI}}\right)$ was calculated as DMI of concentrate and forages multiplied by their estimated $\mathrm{NE}_{\mathrm{L}}$ contents (NRC, 2001). Efficiency of energy utilization was calculated as the ratio of milk energy output to $\mathrm{NE}_{\mathrm{L}}$ consumed. 


\section{El-Bordeny et al.}

\section{Statistical analysis:}

Data obtained from this study were statistically analyzed by SAS (2001) using general linear model with one way analysis of variance, while test the significance among means was used tothe Duncan's multiple range tests (Duncan, 1955).

\section{RESULTS AND DISCUSSION}

\section{Feed intake and digestibility:}

The effect of different feeding levels on feed intake and nutrient digestibilities of dairy buffaloes are presented in Table (2). The results indicated that DMI (kg/day), CP intake (g/day) and $\mathrm{NE}_{\mathrm{L}}(\mathrm{Mcal} / \mathrm{d})$ were significantly and gradually increased $(\mathrm{P}<0.01)$. These results are in agreement with those reported by Vazquez-Anon et al. (1997) who observed that DMI was improved when dietary energy density was increased. However, DMI was not affected by varying feeding levels in other studies for lactating NiliRavi buffaloes (Jabbar et al., 2013) and for lactating dairy cows (Broderick, 2003 and Aghaziarati et al., 2011). Contradictory to the results of recent study, Paul et al. (2003) reported that buffaloes consumption from DMI $(2.57 \mathrm{~kg} \mathrm{DM} / 100 \mathrm{~kg}$ body weight) was significantly $(\mathrm{P}<0.01)$ lower than in cattle $(3.09 \mathrm{~kg}$ $\mathrm{DM} / 100 \mathrm{~kg}$ body weight) in a comparison study to evaluate DMI and nutrient utilization efficiency in lactating cows and buffaloes. This contradiction might be due to the difference in environmental conditions, breeds and feeding strategies.

Table (2): Effect of different feeding levels on feed intake and nutrients digestibility of dairy buffaloes

\begin{tabular}{llllll}
\hline Item & $\mathrm{T}_{1}$ & $\mathrm{~T}_{2}$ & $\mathrm{~T}_{3}$ & SEM & P-value \\
\hline Feed intake & & & & & \\
Dry matter $(\mathrm{kg} / \mathrm{d})$ & $9.46^{\mathrm{c}}$ & $10.99^{\mathrm{b}}$ & $12.02^{\mathrm{a}}$ & 0.24 & 0.001 \\
$\mathrm{CP}(\mathrm{g} / \mathrm{d})$ & $1186.56^{\mathrm{c}}$ & $1378.93^{\mathrm{b}}$ & $1508.43^{\mathrm{a}}$ & 29.78 & 0.001 \\
$\mathrm{NE}_{\mathrm{L}}(\mathrm{Mcal} / \mathrm{d})$ & $16.544^{\mathrm{c}}$ & $19.23^{\mathrm{b}}$ & $21.036^{\mathrm{a}}$ & 0.42 & 0.001 \\
Nutrients digestibility & & & & & \\
Dry matter & 58.38 & 59.81 & 62.13 & 1.527 & 0.199 \\
Organic matter & 63.78 & 63.87 & 65.55 & 1.315 & 0.519 \\
Crude protein & 65.14 & 65.51 & 67.44 & 2.263 & 0.714 \\
Crude fiber & 52.08 & 58.20 & 58.49 & 3.41 & 0.309 \\
\hline$a, b \& c$ cans
\end{tabular}

${ }_{a, b \& c}$ Means at the same row with different superscripts are significantly difference $(P<0.01)$.

On the other hand, DM, OM, CP and CF digestibilities were not significantly ( $\mathrm{P}>0.01)$ affected by feeding lactating buffaloes on different feeding levels. However, it was noted that crude fiber digestibility was increased, numerically, when feeding levels was increased from $80 \%\left(\mathrm{~T}_{1}\right)$ to $100\left(\mathrm{~T}_{2}\right)$ and $120 \%\left(\mathrm{~T}_{3}\right)$ of NRC allowances, but the differences were not significant $(\mathrm{P}>0.01)$. Buffaloes have a good ability for degradation and fermentation of fiber and protein better than cattle and sheep (Sarwar et al., 2009). This good ability to better ferment fiber in buffaloes could be the result of adaptation by feeding on low quality high fibrous feeds (Sarwar et al., 2005). In addition, the results of recent study are in consisting with those obtained by Javaid et al. (2008). They showed a gradual increase in fiber digestibility, greater microbial counts and a linear reduction in $\mathrm{N}$ retention in buffalo bulls with increasing level of ruminally degradable protein (RDP).

\section{Blood metabolites:}

The results of some blood metabolites affected by different feeding levels of dairy buffaloes are presented in Table (3). The results clearly indicated that total protein was significantly $(\mathrm{P}<0.01)$ affected by treatments. The values were 5.99, 6.02 and $6.24 \mathrm{~g} / \mathrm{dl}$ for $\mathrm{T}_{1}, \mathrm{~T}_{2}$ and $\mathrm{T}_{3}$, respectively. This increase in blood total protein could be due to increasing feeding level, which increase RDP level. However, serum albumin, globulin and $\mathrm{A} / \mathrm{G}$ ratio were not significantly, affected by treatments. Blood urea has a significance difference $(\mathrm{P}=0.037)$ between $\mathrm{T}_{2}$ and $\mathrm{T}_{3}$, however, the significance difference between $\mathrm{T}_{1}$ and other treatments was not found. 
Egyptian J. Nutrition and Feeds (2017)

Table (3): Effect of different feeding levels on some blood metabolites of dairy buffaloes

\begin{tabular}{llllll}
\hline Item & $\mathrm{T}_{1}$ & $\mathrm{~T}_{2}$ & $\mathrm{~T}_{3}$ & $\mathrm{SE}$ & $\mathrm{P}$-value \\
\hline Total Protein, g/dl & $5.99^{\mathrm{c}}$ & $6.02^{\mathrm{b}}$ & $6.24^{\mathrm{a}}$ & 0.05 & 0.001 \\
Albumin, g/dl & 3.74 & 3.51 & 3.69 & 0.167 & 0.552 \\
Globulin, g/dl & 2.25 & 2.50 & 2.57 & 0.158 & 0.299 \\
A/G ration & 1.96 & 1.60 & 1.94 & 0.204 & 0.332 \\
Creatinin, $\mathrm{mg} / \mathrm{dl}$ & 0.91 & 0.86 & 0.91 & 0.081 & 0.857 \\
Urea, mg/dl & $50.43^{\mathrm{ab}}$ & $60.63^{\mathrm{a}}$ & $42.79^{\mathrm{b}}$ & 5.08 & 0.037 \\
\hline$a, b \& c$ & Means at the same row with different superscripts are significantly difference $(P<0.01)$.
\end{tabular}

\section{Milk production and composition:}

Milk yield, milk composition percentage and yield and feed conversion results affected by feeding lactating buffaloes on different feed levels are presented in Table (4). A gradual increase $(\mathrm{P}<0.01)$ in milk yield (kg/day), 4\%FCM (kg/day) and ECM (kg/day) was observed. The optimum performance for milk yield was observed when lactating buffaloes were fed on diet performed as $120 \%$ of NRC allowances for cattle $\left(\mathrm{T}_{3}\right)$. These results confirm that the NRC requirements for large dairy cattle breeds are not enough for Egyptian dairy buffaloes concerned in this study. Further, in recent study, feed Egyptian buffaloes above NRC requirements $\left(\mathrm{T}_{3}\right)$ has an advantage and increased milk yield by $18.9 \%$ than animals fed $100 \%$ NRC allowances $\left(\mathrm{T}_{2}\right)$ and it is detrimental to feeding buffaloes below of $120 \%$ of NRC requirements because it will decreased milk yield as it shown with $\mathrm{T}_{1}$.

Table (4): Effect of different feeding levels on milk yield, milk composition (\%), milk content yield (g) and feed efficiency of dairy buffaloes.

\begin{tabular}{|c|c|c|c|c|c|}
\hline Item & $\mathrm{T}_{1}$ & $\mathrm{~T}_{2}$ & $\mathrm{~T}_{3}$ & \pm SEM & $\mathrm{P}$-value \\
\hline \multicolumn{6}{|l|}{ Milk yield (kg/d): } \\
\hline Milk yield (kg/d) & $5.75^{\mathrm{c}}$ & $7.51^{\mathrm{b}}$ & $8.93^{\mathrm{a}}$ & 0.26 & 0.001 \\
\hline $4 \%$ FCM $(\mathrm{kg} / \mathrm{d})$ & $8.47^{\mathrm{c}}$ & $10.88^{\mathrm{b}}$ & $13.7^{\mathrm{a}}$ & 0.35 & 0.001 \\
\hline $\operatorname{ECM}(\mathrm{kg} / \mathrm{d})$ & $9.00^{\mathrm{c}}$ & $11.65^{\mathrm{b}}$ & $13.93^{\mathrm{a}}$ & 0.38 & 0.001 \\
\hline \multicolumn{6}{|l|}{ Milk composition \%: } \\
\hline Fat & 7.19 & 7.04 & 7.13 & 0.11 & 0.61 \\
\hline Protein & $4.33^{\mathrm{b}}$ & $4.42^{\mathrm{a}}$ & $4.37^{\mathrm{ab}}$ & 0.02 & 0.03 \\
\hline Lactose & 4.73 & 4.79 & 4.80 & 0.08 & 0.81 \\
\hline $\mathrm{TS}$ & 17.06 & 17.05 & 17.10 & 0.10 & 0.92 \\
\hline SNF & 9.88 & 10.01 & 9.98 & 0.09 & 0.57 \\
\hline \multicolumn{6}{|l|}{ Milk content yield $(\mathrm{g} / \mathrm{d})$ : } \\
\hline Fat & $411.25^{\mathrm{c}}$ & $525.25^{\mathrm{b}}$ & $633.50^{\mathrm{a}}$ & 17.00 & 0.001 \\
\hline Protein & $249.00^{c}$ & $332.00^{\mathrm{b}}$ & $389.43^{\mathrm{a}}$ & 11.49 & 0.001 \\
\hline Lactose & $271.63^{c}$ & $359.81^{\mathrm{b}}$ & $427.31^{\mathrm{a}}$ & 13.16 & 0.001 \\
\hline SNF & $567.38^{\mathrm{c}}$ & $751.50^{\mathrm{b}}$ & $888.13^{\mathrm{a}}$ & 25.82 & 0.001 \\
\hline $\mathrm{TS}$ & $978.44^{\mathrm{c}}$ & $1276.88^{b}$ & $1521.63^{\mathrm{a}}$ & 40.84 & 0.001 \\
\hline \multicolumn{6}{|l|}{ Feed efficiency: } \\
\hline kg MY/kg DM intake & $0.603^{\mathrm{c}}$ & $0.681^{\mathrm{b}}$ & $0.741^{\mathrm{a}}$ & 0.015 & 0.001 \\
\hline $\mathrm{kg} 4 \% \mathrm{FCM} / \mathrm{kg}$ DM intake & $0.888^{\mathrm{c}}$ & $0.989^{b}$ & $1.087^{\mathrm{a}}$ & 0.021 & 0.001 \\
\hline $\mathrm{kg} \mathrm{ECM} / \mathrm{kg}$ DM intake & $0.943^{\mathrm{c}}$ & $1.059^{\mathrm{b}}$ & $1.158^{\mathrm{a}}$ & 0.023 & 0.001 \\
\hline
\end{tabular}

The results of this study are in line with those reported by Grummer et al. (1995). They found increase in milk yield when lactating animals were fed diets above NRC recommendation. In addition, feeding a balanced ration improved $(\mathrm{P}<0.05)$ milk production and $6 \% \mathrm{FCM}$ yield in buffaloes (Sherasia et al., 2014).

Conversely, our results are in contradiction with those reported by Patton et al. (2006) and Jabbar et al. (2013). They confirmed that the NRC allowances for large dairy breed cows are suitable for Nili-Ravi buffaloes and there is no advantage to increasing feeding for lactating buffaloes above NRC requirements. The difference between these studies may be due to the difference in species and the area of management. 


\section{El-Bordeny et al.}

The results of Table (4) showed that the milk composition are not significantly $(\mathrm{P}>0.01)$ affected by changing feeding levels for lactating buffaloes, except, milk total protein which significantly $(\mathrm{P}=0.03)$ increased by feeding buffaloes with $100 \%$ of NRC requirements $\left(\mathrm{T}_{2}\right)$ than those fed $80 \%$ of $\mathrm{NRC}$ requirements $\left(T_{1}\right)$ but the differences were not significant $(P>0.01)$ between $T_{2}$ and $T_{3}$. These results are in agreement with the results found by Jabbar et al. (2013) who reported that the contents of milk fat, protein, lactose, solids not fat and total solids were not affected $(\mathrm{P}>0.01)$ by varying dietary energy levels in lactating Nili-Ravi buffaloes. The same results were reported for lactating cows (Aghaziarati et al., 2011). However, milk contents yield was significantly $(\mathrm{P}<0.01)$ and gradually increased by gradual increasing of feeding level for lactating buffaloes. Increasing DMI by increasing feeding level according to NRC allowances would increase the quantities of fermentation and digestion process end products (VFA, amino acids ...etc) leading to gradual increase in milk yield and thereby gradual increase in milk contents yield. Milk content yield (fat, protein, lactose, SNF and TS) followed a pattern similar to that of milk yield.

Feed conversion ( $\mathrm{kg}$ produced milk/kg DM intake) for milk yield, 4\% FCM and ECM affected by different feeding levels fed to lactating buffaloes results are illustrated in Table 4 . The results showed that the feed conversion values were significantly $(\mathrm{P}<0.01)$ and gradually increased by increasing feeding levels according to NRC requirements. Meaning that, the efficiency of feed intake was enhanced by increasing feeding level for lactating buffaloes from $80 \%\left(\mathrm{~T}_{1}\right)$ to $100 \%\left(\mathrm{~T}_{2}\right)$ then $120 \%\left(\mathrm{~T}_{3}\right)$ of $\mathrm{NRC}$ allowances for big breeds of dairy cattle. These results are in agreement with findings of Jabbar et al. (2013). They reported that Feed efficiency (FCM/ DMI) was affected by changing energy levels of diets. In the optimum performance realized in diets performed with $100 \%$ and $120 \%$ of NRC energy requirements. Similarly, milk production efficiency (FCM kg/kg DMI) was improved $(\mathrm{P}<0.05)$ to 0.68 from 0.62 when lactating buffaloes were fed on an energy balanced ration (Sherasia et al., 2014). In addition, our findings are partly in accordance with the studies reported by Broderick (2003) and TarazonHerrera et al. (2000). They found that increasing feed efficiency (milk yield/DMI) was increased by increasing dietary energy in diet up to recommended level in lactating cows.

\section{Nutrients efficiency of utilization:}

Effect of different feeding levels on energy balance, nitrogen efficiency of utilization of dairy buffaloes results are presented in Table (5). The results showed that the $\mathrm{NE}_{\mathrm{L}}$ intake/d was significantly and gradually increased when lactating buffaloes were fed $80 \%$ up to $120 \%$ of NRC requirements. Milk energy output (Mcal/d) was significantly and gradually increased. Maintenance energy requirements (Mcal/d) were not significantly affected by increasing feeding level from $80\left(\mathrm{~T}_{1}\right)$ to $100 \%\left(\mathrm{~T}_{2}\right)$ of $\mathrm{NRC}$ allowances, while, it was significantly increased with $120 \%\left(\mathrm{~T}_{3}\right)$ of NRC allowances. Energy balance (M $\mathrm{cal} / \mathrm{d})$ was significantly increased from $80 \%\left(\mathrm{~T}_{1}\right)$ to $100\left(\mathrm{~T}_{2}\right)$ and $120 \%\left(\mathrm{~T}_{3}\right)$ of NRC allowances, however, no significant difference was shown between $\mathrm{T}_{2}$ and $\mathrm{T}_{3}$. Moreover, energy efficiency $(\%)$ was gradually increased but the only significant value was shown when lactating buffaloes were fed with $120 \%$ of NRC allowances $\left(\mathrm{T}_{3}\right)$.

Table (5): Effect of different feeding levels on energy balance and nitrogen efficiency of utilization of dairy buffaloes

\begin{tabular}{|c|c|c|c|c|c|}
\hline Item & $\mathrm{T}_{1}$ & $\mathrm{~T}_{2}$ & $\mathrm{~T}_{3}$ & SEM & P-value \\
\hline \multicolumn{6}{|l|}{ nergy balance, Mcal/day } \\
\hline $\mathrm{NE}_{\mathrm{L}}$ intake, Mcal/ d & $16.544^{\mathrm{c}}$ & $19.23^{\mathrm{b}}$ & $21.036^{\mathrm{a}}$ & 0.42 & 0.001 \\
\hline Milk energy output, Mcal/ d & $6.225^{\mathrm{c}}$ & $8.060^{\mathrm{b}}$ & $9.638^{\mathrm{a}}$ & 0.261 & 0.001 \\
\hline Maintenance requirements, Mcal/ d & $8.403^{\mathrm{b}}$ & $8.403^{\mathrm{b}}$ & $9.109^{\mathrm{a}}$ & 0.154 & 0.002 \\
\hline Energy balance, Mcal/ d & $1.916^{\mathrm{b}}$ & $2.767^{\mathrm{a}}$ & $2.289^{\mathrm{a}}$ & 0.263 & 0.086 \\
\hline Energy efficiency, \% & $37.6^{\mathrm{b}}$ & $41.9^{\mathrm{b}}$ & $45.8^{\mathrm{a}}$ & 0.010 & 0.001 \\
\hline \multicolumn{6}{|l|}{ Nitrogen efficiency of utilization ${ }^{*}$} \\
\hline Nitrogen intake, $\mathrm{g} / \mathrm{d}$ & $189.84^{\mathrm{c}}$ & $220.62^{b}$ & $241.36^{\mathrm{a}}$ & 4.77 & 0.001 \\
\hline Apparent $\mathrm{N}$ digestibility, $\%$ & 65.14 & 65.51 & 67.44 & 2.263 & 0.714 \\
\hline Absorbed N, g/d & $122.92^{\mathrm{c}}$ & $142.23^{\mathrm{b}}$ & $162.32^{\mathrm{a}}$ & 3.24 & 0.001 \\
\hline Milk N output, g/d & $39.01^{\mathrm{c}}$ & $52.04^{\mathrm{b}}$ & $61.05^{\mathrm{a}}$ & 1.80 & 0.001 \\
\hline Milk N/ N intake, $\%$ & $20.37^{\mathrm{b}}$ & $23.56^{\mathrm{a}}$ & $25.13^{\mathrm{a}}$ & 0.01 & 0.001 \\
\hline
\end{tabular}

${ }^{a, b \& c}$ Means at the same row with different superscripts are significantly difference $(P<0.01)$.

* Nitrogen efficiency of utilization $=$ Nitrogen in feeds $(g) /$ nitrogen in milk $(g) * 100$. 
Concerning to nitrogen efficiency and utilization, the results of Table (5) showed that nitrogen intake $(\mathrm{g} / \mathrm{d})$ was significantly increased as a result for increasing dry matter intake with its content of crude protein. However, the apparent $\mathrm{N}$ digestibility (\%) was not significantly affected by varying feeding levels to lactating buffaloes. The absorbed $\mathrm{N}(\mathrm{g} / \mathrm{d})$ and milk $\mathrm{N}$ output $(\mathrm{g} / \mathrm{d})$ were gradually and significantly increased from $T_{1}$ to $T_{3}$. The nitrogen efficiency (milk N/N intake \%) was significantly increased when feeding levels were increased from 80 to $100 \%$ and $120 \%$ of NRC allowances but no significance difference between $T_{2}$ and $T_{3}$ was detected.

\section{CONCLUSION}

It could be concluding that NRC recommendations for dairy breed cows are not the optimum feeding level for Egyptian buffaloes under the conditions of this study. Feeding lactating buffaloes under NRC requirements is detrimental and it will decrease milk production and feed efficiency. Feeding lactating buffaloes above NRC allowances could increase milk production and feed efficiency and thereby the profitability for dairy buffaloes breeders. Further studies under different conditions should be conducted to find the optimum requirements for feeding buffaloes in Egypt.

\section{REFERENCES}

Aghaziarati, N.; H. Amanlou; D. Zahmatkesh; E. Mahjoubi and M.H. Yazdi (2011). Enriched dietary energy and protein with more frequent milking offers early lactation cows a greater productive potential. Livestock Sci., 136 (2): 108-113.

AOAC (1995). Official Methods of Analysis. $16^{\text {th }}$ Edn. Association of Official Analytical Chemists, Washington, D.C., USA.

Broderick, G.A. (2003). Effect of varying dietary protein and energy levels on production of lactating dairy cows. J. Dairy Sci., 86: 1370-1381.

Calabro, S.; V. Piccolo and F. Infascelli (2003). Evaluation of diet for buffalo dairy cows using the cornell net carbohydrate and protein system. Asian-Australian. J. of Anim. Sci., 16: 1475-1481.

Duncan, D.B. (1955). Multiple Range and Multiple F Test. Biometrics. 11 (1):1-42.

El-Serafy, A.M. and M.A. El-Ashry (1988). The nutrition of Egyptian water buffaloes from birth to milk and meat production. Proceedings of the International Symposium on the Constraints of Ruminant Production in the Dry Subtropics. Cairo, Egypt, 5-7 Nov., 1988. pp. 230-243, EAAP Pub. No. 38.

FAO (2014). FAOSTAT. Food and Agriculture Organization of the United Nations, Rome, Italy. http://www.fao.org/economic/the-statistics-division.

Franzolin, R. (1994). Feed Efficiency: A comparison between cattle and buffalo. Buffalo J., (Supp. 2): 3950.

Gaines, W.L. (1928). The energy basis of measuring energy milk in dairy cows. Univ., Illinois Agric. Experiment Station. Bulletin No. 308.

Ghoneim, A. (1967). "Animal Nutrition". II. Applied Animal Nutrition. $6^{\text {th }}$ Ed., Anglo, Cairo, Egypt (Arabic).

Gong, J.G.; W.J. Lee; P.C. Garnsworthy and R. Webb (2002). Effect of dietary induced increases in circulating insulin concentrations during the early postpartum period on reproductive function in dairy cows. Reprod., 123: 419-427.

Grummer, R.R. and D.J. Carrol (1988). A review of lipoprotein cholesterol metabolism: Importance to ovarian function. J. Anim. Sci., 66: 3160 -3173.

Grummer, R.R.; F.P.C. Hoffman; M.L. Luck and S.J. Bertics (1995). Effect of pre- partum and postpartum dietary energy on growth and lactation of primiparous cows. J. Dairy Sci., 78: 172180. 


\section{El-Bordeny et al.}

Hoogendoorn, A.L. and C.M. Grieve (1970). Effect of varying energy or roughage in rations for lactating dairy cows on feed intake and milk production. J. Dairy Sci., 48: 1028-1033.

Jabbar, M.A.; M. Fiaz; T. Iqbal; M. Abdullah and I.B. Marghazani (2013). Effect of different dietary energy levels on milk production in lactating Nili-Ravi buffaloes. The Journal of Animal and Plant Sciences, 23(1 Suppl.): 13-16.

Javaid, A.; M.U. Nisa; M. Sarwar and M.A. Shahzad (2008). Ruminal characteristics, blood pH, blood urea nitrogen and nitrogen balance in Nili-ravi Buffalo (Bubalusbubalis) bulls fed diets containing various levels of ruminally degradable protein. Asian-Aust. J. Anim. Sci., 21:51-58.

Kearl, L.C. (1982). Nutrient Requirements of Ruminants in Developing Countries. International Feedstuffs Institute, Utah Agricultural Experiment Station, Utah State University, Logan, Utah, USA.

NRC (2001). Nutrient Requirements of Dairy Cattle. 7th rev. ed. National Academy Press, Washington, DC. $408 \mathrm{p}$.

Patton, J.; D.A. Kenny; J.F. Mee; F.P. O’mara; D.C. Wathes; M. Cook and J.J. Murphy (2006). Effect of milking frequency and diet on milk production, energy balance and reproduction in dairy cows. J. Dairy Sci., 89: 1478-87.

Paul, S.S. (2011). Nutrient requirements of buffaloes. R. Bras. Zootec., v.40, p.93-97.

Paul, S.S. and D. Lal (2010). Nutrient requirements of buffaloes. New Delhi, India, Satish Serial Publishing House, 137p.

Paul, S.S.; A.B. Mandal and N.N. Pathak (2002). Feeding standards for lactating river Nili buffaloes in tropical conditions. J. of Dairy Res., 69:173-180

Paul, S.S.; A.B. Mandal; A. Kannan; G.P. Mandal and N.N. Pathak (2003). Comparative dry matter intake and nutrient utilization efficiency in lactating cattle and buffaloes. J. Sci. Food Agr., 83: 258267.

Sarwar, M.; M.A. Khan and M. Nisa (2005). Chemical composition and feeding value of urea treated corn cobs ensiled with additives for sheep. Aust. J. Agric. Res., 65: 685-690.

Sarwar, M.; M.A. Khan; M. Nisa; S.A. Bhatti and M.A. Shahzad (2009). Nutritional management for buffalo production. Asian-Aust. J. Anim. Sci., 22(7): 1060-1068.

SAS (2001). SAS User's Guide Statistics. Version 8.02, SAS Institute Inc., Cary, NC.

Shehata, E. (1971). "Lectures of Animal Nutrition", Department of Animal Production, Faculty of Agriculture, Ain Shams University, Cairo, Egypt (In Arabic).

Sherasia, P.L.; M.R. Garg and B.M. Bhanderi (2014). Effect of feeding balanced rations on production efficiency and enteric methane emission in lactating buffaloes under tropical conditions. Buffalo Bulletin, 33(4): 323-331.

Tarazon-Herrera, M.A.; J.T. Huber; J.E.P. Santos and L.G. Nussio (2000). Effect of bovine somatotropin on milk yield and composition in Holstein cows in advanced lactation fed low or high energy diets. J. Dairy Sci., 83: 430-434.

Tyrrell, H.F. and J.T. Reid (1965). Prediction of the energy value of cow's milk. J. Dairy Sci., 48: 1215 1223.

Van Keulen, J. and B.A. Young (1977). Evaluation of acid insoluble ash as a natural marker in ruminant digestibility studies. J. Anim. Sci., 44: 282-287.

Van Soest, P.J.; J.B. Robertson and B.A. Lewis (1991). Methods for dietary fiber, neutral detergent fiber and non-starch polysaccharides in relation to animal nutrition. J. Dairy Sci., 74: 3583-3597.

Vazquez-Anon, M.; S.J. Bertics and R.R. Grummer (1997). The effect of dietary energy source on during mid to late lactation on liver triglyceride and lactation performance of dairy cows. J. Dairy Sci., 80: 2504-2512. 
تأثير التغذية بمستويات مختلفة على الأداء الإنتاجى للجاموس المصرى الحلاب

\author{
نصر السيد البردينى1 ، رمضان محمد أحمد عبدالجواد²، حسام محروس عبيد² و عادل عيد محم محمود33 \\ اقسم الإنتاج الحيوانى، كلية الزراعة، جامعة عين شمس، شبرا الخيمة، القليوبية، مصر.

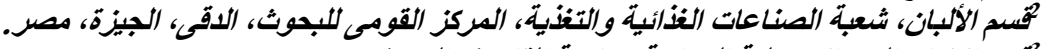

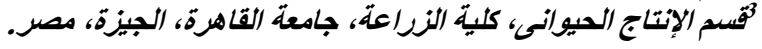

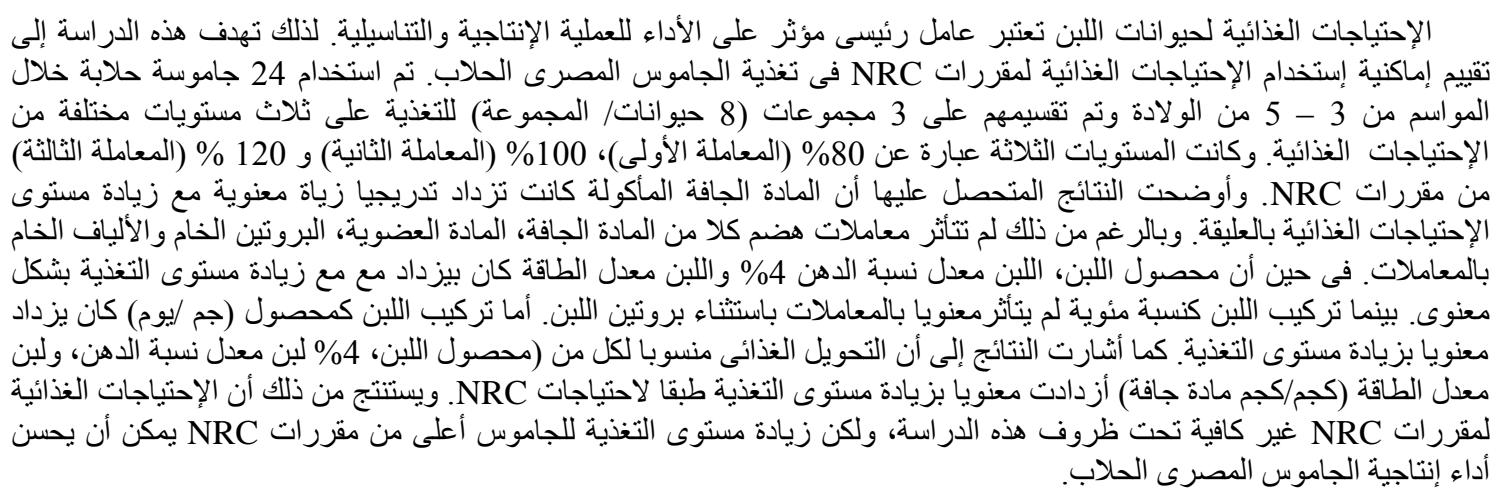

